\title{
PENINGKATAN KEMAMPUAN MENYIMAK PIDATO DENGAN METODE TANYA JAWAB SISWA KELAS IX.2 SMP NEGERI 21 KOTA PEKANBARU
}

\author{
Haryenti \\ SMP Negeri 21 Pekanbaru \\ e-mail: haryenti32@yahoo.com
}

\begin{abstract}
This study aims to determine the improvement of the ability to listen to speech by the method of question and answer students class IX.2 SMP Negeri 21 Pekanbaru City. This study began in August 2015 until the completion of this study. The form of research is classroom action research. The instrument of this research consisted of instrument of learning device and instrument of data collection in the form of observation ability of listening child. Based on the results of the research, it is known that the average ability of students on the initial test is categorized both with an average value of 62 and in the first cycle rose to 71.6 with good category, while in cycle II the average ability of students is also categorized well with the average value average 82.8 , but with $100 \%$ completeness, where the student's mastery score has been met. The above statement shows that the ability to listen to speech with question and answer method in the students of class IX.2 SMP Negeri 21 Pekanbaru City can be improved through question and answer method. Thus the research hypothesis that reads the listening to speech with the method of question and answer in the students of class IX.2 SMP Negeri 21 Pekanbaru City can be "accepted".
\end{abstract}

Keywords - question and answer method, ability to listen to speech

\begin{abstract}
Abstrak
Penelitian ini bertujuan untuk mengetahui peningkatan kemampuan menyimak pidato dengan metode tanya jawab siswa kelas IX.2 SMP Negeri 21 Kota Pekanbaru. Penelitian ini dimulai pada bulan Agustus 2015 hingga selesainya penelitian ini. Bentuk penelitian adalah penelitian tindakan kelas. Instrumen penelitian ini terdiri dari instrumen perangkat pembelajaran dan instrumen pengumpulan data berupa observasi kemampuan menyimak anak. Berdasarkan hasil penelitian, diketahui kemampuan rata-rata siswa pada tes awal dikategorikan baik dengan nilai rata-rata 62 dan pada siklus I naik menjadi 71,6 dengan kategori baik, sedangkan pada siklus II kemampuan rata-rata siswa juga dikategorikan baik dengan nilai rata-rata 82.8, tetapi dengan ketuntasan 100\%, dimana nilai ketuntasan siswa telah tercapi. Pernyataan di atas menunjukkan bahwa kemampuan menyimak pidato dengan metode tanya jawab pada siswa kelas IX.2 SMP Negeri 21 Kota Pekanbaru dapat ditingkatkan melalui metode tanya jawab. Dengan demikian hipotesis penelitian yang berbunyi peningkatan menyimak pidato dengan metode tanya jawab pada siswa kelas IX.2 SMP Negeri 21 Kota Pekanbaru dapat "diterima”.
\end{abstract}

Kata kunci-Metode tanya jawab, kemampuan menyimak pidato

\section{PENDAHULUAN}

Bahasa merupakan sarana untuk saling berkomunikasi, saling berbagi pengalaman, saling belajar dari yang lain dan untuk meningkatkan kemampuan intelektual. Hal ini berarti bahwa bahasa memiliki peran yang penting bagi manusia. Dengan demikian, dapat dimaklumi jika di sekolah terdapat mata pelajaran bahasa, khususnya bahasa Indonesia.

Mata pelajaran Bahasa Indonesia merupakan salah satu sarana yang dapat mengakses berbagai informasi. Untuk itu kemahiran berkomunikasi dalam Bahasa Indonesia secara lisan dan 
tertulis harus benar-benar dimiliki dan ditingkatkan. Oleh sebab itu seorang guru dituntut untuk mampu mencapai kompetensi dasar yang sudah ditetapkan.

Pembelajaran bahasa Indonesia di sekolah diarahkan untuk meningkatkan kemampuan siswa dalam berkomunikasi dengan bahasa Indonesia baik secara lisan maupun tulisan. Untuk mewujudkannya maka pelajaran bahasa Indonesia diprogramkan untuk mengembangkan pengetahuan, sikap positif terhadap bahasa Indonesia dan ketrampilan berbahasa. Adapun ketrampilan berbahasa dalam kurikulum terdiri atas empat aspek, yaitu ketrampilan menyimak, ketrampilan berbicara, ketrampilan membaca dan ketrampilan menulis.

Menurut Tarigan (1998:1) setiap ketrampilan itu erat sekali berhubungan dengan tiga ketrampilan lainnya dengan cara yang beraneka ragam. Dalam memperoleh ketrampilan berbahasa, biasanya melalui suatu hubungan urutan yang teratur: mula-mula pada masa kecil kita belajar menyimak bahasa, kemudian berbicara, sesudah itu belajar membaca dan menulis. Menyimak dan berbicara dipelajari sebelum memasuki sekolah. Keempat ketrampilan tersebut pada dasarnya merupakan satu kesatuan, merupakan catur tunggal. Setiap ketrampilan itu erat pula berhubungan dengan proses-proses berfikir yang mendasari bahasa. Bahasa seseorang mencerminkan pikirannya. Semakin trampil, seseorang berbahasa, semakin cerah dan jelas jalan pikirannya. Ketrampilan hanya dapat diperoleh dan kuasai dengan jalan praktek dan banyak latihan. Melatih ketrampilan berbahasa hanya dapat diperoleh dan kuasai dengan jalan praktek dan banyak latihan. Melatih ketrampilan berbahasa berarti pula melatih ketrampilan berfikir.

Ketrampilan menyimak merupakan salah satu ketrampilan berbahasa yang sangat penting disamping ketiga aspek keterampilan bahasa lainnya. Dalam kehidupan sehari-hari, ketrampilan menyimak merupakan dasar bagi keterampilan berbicara, membaca, dan menulis baik secara langsung maupun tidak langsung.

Sebagaimana dikemukakan oleh Razak (2006:2) menyimak merupakan salah satu bagian dari empat komponen bahasa. Menyimak merupakan komponen bahasa tingatan pertama. Sejak manusia masih dalam kandungan proses menyimak sudah mulai berlangsung. Hal ini dapat diterima dimana para ibu-ibu yang sedang hamil dianjurkan untuk memperdengarkan musik-musik lembut berisi ajaran moral yang posistif agar sijabang bayi terbiasa dan peka terhadap apa yang didengarnya.

Hal senada dikemukakan oleh Slamet (2008:8) bahwa belajar berbahasa diawali dengan kegiatan menyimak. Perhatikan anak-anak kecil belajar berbahasa (bahasa ibunya) atau siswa sekolah lanjutan belajar bahasa asing. Pada awalnya, mereka banyak menyimak bahasa target yang ducapkan oleh ibu atau guru mereka. Mereka menyimak bunyi bahasa, kata atau kalimat. Lambat laun mereka menirukan ucapan-ucapan yang disimaknya. Selanjutnya mereka mencoba menerapkan dalam pembicaraan. Proses menyimak, mengartikan makna, meniru dan mempraktikkan bunyi bahasa itu mereka lakukan berulang-ulang, tentu saja dengan berbagai kesalahan atau kekeliruan yang sedikit demi sedikit diperbaiki, sampai akhirnya yang bersangkutan berhasil. Dengan demikian dapat dinyatakan dengan menyimak merupakan dasar atau landasan belajar berbahasa.

Berdasarkan paparan di atas, diketahui betapa pentingnya kegiatan menyimak merupakan keterampilan bahasa yang berperan penting dalam belajar berbahasa. Melalui menyimak seseorang dapat menguasai pengucapan fonem, kosakata dan kalimat. Pemahaman terhadap hal ini sangat membantu yang bersangkutan dalam berbagai kegiatan, seperti berbicara, membaca dan menulis.

Berdasarkan hasil pengamatan selama peneliti bertugas di SMP Negeri 21 Kota Pekanbaru ditemui gejala-gejala atau fenomena khususnya pada aspek kemampuan menyimak pidato yaitu, sebagai berikut:

1) Rendahnya kemampuan siswa dalam menyimak pidato. Dari 40 orang siswa hanya 9\% siswa yang dapat menyimak dengan baik, sedangkan sisanya belum dapat menyimak dengan baik. Sedangkan secara klasikal kemampuan siswa masih tergolong cukup.

2) Rendahnya hasil belajar siswa, khusunya dari aspek menyimak pidato.

3) Kurangnya pemahaman siswa dalam memahami aspek-aspek yang terkandung dalam suatu pidato, baik sifat bahan, pengorganisasian bahan dan bahasa bahan.

Dari fenomena-fenomena atau gejala-gejala tersebut di atas, terlihat rendahnya kemampuan siswa dalam menyimak pidato. Keadaan di atas menurut penulis dipengaruhi oleh 
metode atau cara mengajar guru yang kurang sesuai dengan materi yang diajarkan. Guru cenderung melaksanakan pembelajaran dengan ceramah atau penugasan sehingga membuat siswa kurang aktif dan kualitas pembelajaran terkesan rendah. Melalui metode tanya jawab terjadi interaksi dua arah, antara guru dan siswa dan sebaliknya, sehingga mendukung tercapainya hasil belajar yang optimal.

Oleh sebab itu peneliti tertarik ingin melakukan suatu penelitian tindakan sebagai upaya dalam melakukan perbaikan terhadap hasil pembelajaran dengan judul "Peningkatan kemampuan menyimak pidato dengan metode tanya jawab siswa kelas IX.2 SMP Negeri 21 Kota Pekanbaru".

\section{METODE}

Penelitian tindakan kelas ini dilaksanakan SMP Negeri 21 Kota Pekanbaru pada siswa kelas IX.2. Adapun penelitian ini dimulai pada bulan Agustus 2015 hingga selesainya penelitian ini. Subjek penelitian ini adalah siswa kelas IX. 2 SMP Negeri 21 Kota Pekanbaru dengan jumlah siswa sebanyak 40 orang. Untuk mengumpulkan data penelitian, peneliti menggunakan dua alat yaitu berupa tes dan nontes. Teknik tes digunakan untuk menjaring data berkaitan dengan kemampuan siswa dalam menyimak pidato. Sedangkan teknik non tes adalah teknik yang digunakan peneliti dalam rangka menilai keberhasilan dan kekurangberhasilan proses pembelajaran yang dilakukan.

Menjaring data dengan teknik tes dengan cara meminta siswa mendengarkan pidato. Setelah itu, siswa diminta untuk mengerjakan tugas yang diberikan oleh peneliti. Pemberian tugas ini selalu berkaitan dengan materi pelajaran.

Penerapan teknik non tes dalam rangka menjaring data penelitian yaitu, peneliti dan observer melakukan pengamatan serta mencatat hal-hal yang dilakukan oleh peneliti.

\section{Teknik Analisis Data}

1. Kemampuan menyimak pidato

Untuk mengetahui kemampuan siswa dalam menyimak pidato, penulis menggunakan tes hasil belajar. Adapun penilaian kemampuan menyimak pidato memuat 3 aspek. Adapun aspekaspek tersebut yaitu:

1) Menulis pesan atau anjuran, rentang skor 0 - 30

2) Menyimpulkan hal-hal penting, rentang skor $0-30$

3) Menyampaikan hasil simpulan yang telah dibuat, $0-40$

Selanjutnya untuk memberikan interprestasi terhadap skor siswa mengacu pada interval skor penilaian. Ketuntasan individu tercapai apabila siswa mencapai nilai 70 .

\section{Tabel 1}

Interval Kategori Kemampuan Menyimak Pidato

\begin{tabular}{|c|c|c|}
\hline No & Interval (\%) & Kategori \\
\hline 1 & $81-100$ & Baik Sekali \\
\hline 2 & $60-80$ & Baik \\
\hline 3 & $41-59$ & Cukup \\
\hline 4 & $21-40$ & Kurang \\
\hline 5 & $0-20$ & Sangat kurang \\
\hline
\end{tabular}

Safari (2005)

Ketuntasan klasikal tercapai apabila $80 \%$ dari seluruh siswa mampu menyimak pidato dengan nilai minimal 70 maka kelas itu dikatakan tuntas. Adapun rumus yang dipergunakan untuk menentukan ketuntasan klasikal sebagai berikut:

$$
\begin{aligned}
K K & =\frac{J T}{J S} \times 100 \% \\
\text { KK } & =\text { Ketuntasan klasikal } \\
\text { JT } & =\text { Jumlah siswa yang tuntas } \\
\text { JS } & =\text { Jumlah siswa seluruhnya }
\end{aligned}
$$




\section{Aktivitas guru}

Aktivitas guru selama kegiatan belajar mengajar yang dibukukan pada observasi dengan rumus:

$$
\begin{aligned}
& P=\frac{F}{N} \times 100 \% \\
& \mathrm{P}=\text { Angka persentase } \\
& \mathrm{F} \quad=\text { Frekuensi aktivitas guru } \\
& \mathrm{N} \quad=\text { Jumlah aktivitas }
\end{aligned}
$$

\section{HASIL DAN PEMBAHASAN}

\section{Hasil Penelitian}

\section{Siklus Pertama}

Data yang menunjukkan kegiatan siswa pada tindakan siklus I tercantum pada lembaran observasi. Yang bertindak sebagai observer adalah teman sejawat yang bernama Marlis. Pada lembaran observasi tergambar bahwa:

(1) Semangat atau motivasi belajar siswa saat penelitian ini dilakukan cukup baik. Penelitian yang diberikan pada lembaran observasi (A). Peneliti menyatakan hal ini karena pada saat kegiatan pembelajaran berlangsung semua siswa serius. Di samping itu, siswa juga asik menyimak pidato yang dibagikan peneliti.

(2) Semua siswa menyimak pidato dengan serius. Namun hasil yang diperoleh siswa pada

\begin{tabular}{|c|c|c|c|c|c|c|c|c|c|c|c|c|c|c|c|c|c|c|}
\hline \multirow[b]{2}{*}{ No } & \multirow[b]{2}{*}{ Kode Sampel } & \multicolumn{14}{|c|}{ Aktivitas Siswa } & \multirow[b]{2}{*}{ Skor } & \multirow[b]{2}{*}{ Nilai } & \multirow[b]{2}{*}{ Kategori } \\
\hline & & 1 & 2 & 3 & 4 & 5 & 6 & 7 & 8 & 9 & 10 & 11 & 12 & 13 & 14 & & & \\
\hline 1 & Adinda Fahira & 1 & 0 & 1 & 0 & 1 & 1 & 0 & 1 & 1 & 1 & 0 & 1 & 1 & 0 & 9 & 64 & Baik \\
\hline 2 & Aisyah Evlina & 0 & 1 & 0 & 1 & 0 & 0 & 1 & 1 & 0 & 1 & 1 & 1 & 1 & 1 & 9 & 64 & Baik \\
\hline 3 & Aldo Putra & 1 & 1 & 1 & 1 & 1 & 1 & 0 & 1 & 1 & 1 & 0 & 1 & 0 & 1 & 11 & 79 & Baik \\
\hline 4 & Ana Putra & 1 & 0 & 0 & 1 & 0 & 1 & 1 & 0 & 1 & 1 & 1 & 0 & 1 & 0 & 8 & 57 & Cukup \\
\hline 5 & \begin{tabular}{|l|} 
Andre Fajri Ananda \\
\end{tabular} & 0 & 1 & 0 & 1 & 1 & 1 & 1 & 1 & 1 & 0 & 1 & 1 & 1 & 1 & 11 & 79 & Baik \\
\hline 6 & \begin{tabular}{|l} 
andreas Ajis Saputra \\
\end{tabular} & 1 & 0 & 1 & 1 & 0 & 0 & 1 & 0 & 0 & 1 & 0 & 1 & 1 & 1 & 8 & 57 & Cukup \\
\hline 7 & Anggi Riyanta & 0 & 0 & 0 & 1 & 0 & 0 & 1 & 1 & 1 & 1 & 1 & 1 & 1 & 1 & 9 & 64 & Baik \\
\hline 8 & Atsa Putri Jannah & 1 & 1 & 1 & 1 & 1 & 1 & 1 & 1 & 1 & 0 & 1 & 1 & 1 & 0 & 12 & 86 & Baik Sekali \\
\hline 9 & Astri Permata Sari & 0 & 0 & 1 & 0 & 1 & 1 & 0 & 0 & 1 & 1 & 0 & 1 & 1 & 1 & 8 & 57 & Cukup \\
\hline 10 & $\begin{array}{l}\text { Catur Ramadhan } \\
\end{array}$ & 0 & 1 & 0 & 0 & 0 & 0 & 1 & 1 & 0 & 1 & 1 & 1 & 1 & 1 & 8 & 57 & Cukup \\
\hline 11 & $\begin{array}{l}\text { Devid Falen } \\
\end{array}$ & 1 & 0 & 1 & 0 & 1 & 1 & 1 & 1 & 1 & 0 & 1 & 0 & 1 & 0 & 9 & 64 & Baik \\
\hline 12 & \begin{tabular}{|l} 
Dhea Sulastri Dasnan \\
\end{tabular} & 0 & 1 & 1 & 1 & 0 & 1 & 0 & 1 & 0 & 1 & 0 & 1 & 0 & 1 & 8 & 57 & Cukup \\
\hline 13 & \begin{tabular}{|l} 
Elya Cintana Fahrezy \\
\end{tabular} & 1 & 0 & 1 & 1 & 1 & 0 & 1 & 1 & 1 & 0 & 1 & 0 & 1 & 1 & 10 & 71 & Baik \\
\hline 14 & Gempi Yuluandi & 0 & 1 & 0 & 1 & 1 & 1 & 0 & 0 & 0 & 1 & 1 & 1 & 1 & 0 & 8 & 57 & Cukup \\
\hline 15 & Ismi Dehanindah & 1 & 0 & 1 & 0 & 1 & 1 & 0 & 1 & 1 & 1 & 0 & 1 & 1 & 0 & 9 & 64 & Baik \\
\hline 16 & Laray Baffi & 0 & 1 & 0 & 1 & 0 & 0 & 1 & 1 & 0 & 1 & 1 & 1 & 1 & 1 & 9 & 64 & Baik \\
\hline 17 & Mitra Lestari & 1 & 1 & 1 & 1 & 1 & 1 & 0 & 1 & 1 & 1 & 0 & 1 & 0 & 1 & 11 & 79 & Baik \\
\hline 18 & M. Akbar Zidang & 1 & 0 & 0 & 1 & 0 & 1 & 1 & 0 & 1 & 1 & 1 & 0 & 1 & 0 & 8 & 57 & Cukup \\
\hline 19 & \begin{tabular}{|l|} 
M. Farhan Athaullah \\
\end{tabular} & 0 & 1 & 0 & 1 & 1 & 1 & 1 & 1 & 1 & 0 & 1 & 1 & 1 & 1 & 11 & 79 & Baik \\
\hline 20 & \begin{tabular}{|l|} 
M. Ikhsan Alfathan \\
\end{tabular} & 1 & 0 & 1 & 1 & 0 & 0 & 1 & 0 & 0 & 1 & 0 & 1 & 1 & 1 & 8 & 57 & Cukup \\
\hline 21 & M. Salman & 0 & 0 & 0 & 1 & 0 & 0 & 1 & 1 & 1 & 1 & 1 & 1 & 1 & 1 & 9 & 64 & Baik \\
\hline 22 & M. Subarja & 1 & 1 & 1 & 1 & 1 & 1 & 1 & 1 & 1 & 0 & 1 & 1 & 1 & 0 & 12 & 86 & Baik Sekali \\
\hline 23 & Nabila Ariesta & 0 & 0 & 1 & 0 & 1 & 1 & 0 & 0 & 1 & 1 & 0 & 1 & 1 & 1 & 8 & 57 & Cukup \\
\hline 24 & Nanda Nugroho & 0 & 1 & 0 & 0 & 0 & 0 & 1 & 1 & 0 & 1 & 1 & 1 & 1 & 1 & 8 & 57 & Cukup \\
\hline 25 & Mathania Azaria & 1 & 0 & 1 & 0 & 1 & 1 & 1 & 1 & 1 & 0 & 1 & 0 & 1 & 0 & 9 & 64 & Baik \\
\hline 26 & Nurul Anjalina & 0 & 1 & 1 & 1 & 0 & 1 & 0 & 1 & 0 & 1 & 0 & 1 & 0 & 1 & 8 & 57 & Cukup \\
\hline 27 & Nurul Annisa S & 1 & 0 & 1 & 1 & 1 & 0 & 1 & 1 & 1 & 0 & 1 & 0 & 1 & 1 & 10 & 71 & Baik \\
\hline 28 & Nyimas Adelia. $\mathrm{H}$ & 0 & 1 & 0 & 1 & 1 & 1 & 0 & 0 & 0 & 1 & 1 & 1 & 1 & 0 & 8 & 57 & Cukup \\
\hline 29 & Puji Lestari & 1 & 1 & 1 & 0 & 1 & 0 & 0 & 0 & 1 & 0 & 1 & 0 & 0 & 1 & 7 & 50 & Cukup \\
\hline 30 & Rahmad Dail & 1 & 1 & 1 & 0 & 1 & 0 & 0 & 0 & 1 & 0 & 1 & 0 & 0 & 1 & 7 & 50 & Cukup \\
\hline 31 & Ridho Fadillah & 1 & 0 & 1 & 0 & 1 & 1 & 1 & 0 & 1 & 1 & 0 & 1 & 0 & 0 & 8 & 57 & Cukup \\
\hline 32 & Rio Ahmad & 1 & 1 & 1 & 1 & 0 & 0 & 1 & 1 & 0 & 0 & 1 & 0 & 1 & 1 & 9 & 64 & Baik \\
\hline 33 & Riska Amelia Putri & 0 & 1 & 0 & 0 & 0 & 0 & 1 & 1 & 0 & 1 & 1 & 1 & 1 & 1 & 8 & 57 & Cukup \\
\hline 34 & Siti Zharifah & 1 & 0 & 1 & 0 & 1 & 1 & 1 & 1 & 1 & 0 & 1 & 0 & 1 & 0 & 9 & 64 & Baik \\
\hline 35 & \begin{tabular}{|l|} 
Tahnia Insan Nuraini \\
\end{tabular} & 0 & 1 & 1 & 1 & 0 & 1 & 0 & 1 & 0 & 1 & 0 & 1 & 0 & 1 & 8 & 57 & Cukup \\
\hline 36 & Taufik Hatta & 1 & 0 & 1 & 1 & 1 & 0 & 1 & 1 & 1 & 0 & 1 & 0 & 1 & 1 & 10 & 71 & Baik \\
\hline 37 & Trisna Amalia & 0 & 1 & 0 & 1 & 1 & 1 & 1 & 1 & 1 & 0 & 1 & 1 & 1 & 1 & 11 & 79 & Baik \\
\hline 38 & William Faranuari & 1 & 0 & 1 & 1 & 0 & 0 & 1 & 0 & 0 & 1 & 0 & 1 & 1 & 1 & 8 & 57 & Cukup \\
\hline 39 & $\begin{array}{l}\text { Yolanda } \\
\end{array}$ & 0 & 0 & 0 & 1 & 0 & 0 & 1 & 1 & 1 & 1 & 1 & 1 & 1 & 1 & 9 & 64 & Baik \\
\hline 40 & Yudhi Pratama & 1 & 0 & 1 & 0 & 1 & 1 & 0 & 1 & 1 & 1 & 1 & 1 & 0 & 1 & 10 & 71 & Baik \\
\hline & $\begin{array}{l}\text { Jumlah } \\
\end{array}$ & 22 & 20 & 25 & 26 & 23 & 23 & 26 & 28 & 26 & 26 & 27 & 29 & 31 & 28 & 360 & 2571.4 & \\
\hline & $\begin{array}{l}\text { Rata-rata } \\
\end{array}$ & $55.0 \%$ & $50.0 \%$ & $62.5 \%$ & $65.0 \%$ & $57.5 \%$ & $57.5 \%$ & $65.0 \%$ & $70.0 \%$ & $65.0 \%$ & $65.0 \%$ & $67.5 \%$ & $72.5 \%$ & $77.5 \%$ & $70.0 \%$ & 20.0 & $64.3 \%$ & Baik \\
\hline & $\begin{array}{l}\text { Kategori } \\
\end{array}$ & & & & & & & & $\mathrm{Ba}$ & & & & & & & & & \\
\hline
\end{tabular}
tindakan siklus I belum memuaskan, karena belum mencapai nilai ketuntasan yang ditetapkan (78).

(3) TABEL 3

OBSERVASI AKTIVITAS SISWA SIKLUS I

Sumber: Data hasil olahan penelitian, 2015 
Sebagaiman terlihat pada tabel 5, bahwa aktivitas siswa masih kurang optimal dalam mengikuti proses pembelajaran. Hal itu dapat dilihat pada rincian berikut:

1. Pada aspek memperhatikan penjelasan guru dengan penuh khidmat yang memperoleh nilai dengan persentase $55,0 \%$ (22 siswa dari 40 orang).

2. Pada aspek memperhatikan dan melaksanakan perintah guru hanya memperoleh nilai dengan persentase $50 \%$, (20 siswa dari 40 orang),

3. Pada aspek memperhatikan pengarahan guru memperoleh persentase nilai $62.5 \%$ (25 siswa Dari 40 orang jumlah siswa),

4. Pada aspek mendengarkan penjelasan guru tentang topik, tujuan dan hasil belajar diperoleh nilai persentase $65 \%$ (26 siswa dari 40 orang),

5. Pada aspek mendengarkan pokok-pokok kegiatan yang harus dilakukan memperoleh nilai $57.5 \%$ (23 siswa dari 40 orang jumlah siswa),

6. Pada aspek mendengarkan pentingnya topik dan kegiatan belajar nilai persentase $65 \%$ (26 siswa dari 40 orang jumlah siswa),

7. Pada aspek menjawab pertanyaan guru memperoleh nilai persentase $70 \%$ (28 siswa dari 40 orang jumlah siswa),

8. Pada aspek aktif dalam kegiatan tanya jawabmemperoleh nilai persentase $65 \%$ (26 siswa dari 40 orang jumlah siswa),

9. Pada aspek menyimpulkan hasil tanya jawab memperoleh nilai persentase $67.5 \%$ (26 siswa dari 40 orang jumlah siswa),

10.Pada aspek menjawab pertanyaan guru dengan benar memperoleh nilai persentase $72.5 \% 29$ siswa dari 40 orang jumlah siswa),

11.Pada aspek mengikuti evaluasi dengan baik memperoleh nilai persentase $77.5 \%$ (31 siswa Dari 40 orang jumlah siswa),

12. Pada aspek menerima hasil penilaian dari guru memperoleh nilai persentase $70 \%$ (28 siswa Dari 40 orang jumlah siswa),

13. Pada aspek mendengarkan penyampaian guru diakhir pembelajaran memperoleh nilai persentase $70.0 \%$ (28 siswa Dari 40 orang),

14.Pada aspek mengikuti guru menutup pelajaran memperoleh nilai persentase $70 \%$ (28 siswa Dari 40 orang jumlah siswa).

Nilai rata-rata persentase aktivitas siswa pada siklus I adalah 64,3\% dengan kategori baik.

TABEL 4

OBSERVASI AKTIVITAS GURU SIKLUS I

\begin{tabular}{|c|c|c|c|c|c|c|c|c|c|}
\hline \multirow[b]{2}{*}{ No } & \multirow[b]{2}{*}{ Aktivitas } & \multicolumn{5}{|c|}{ Skala nilai } & \multirow{2}{*}{ Skor } & \multirow{2}{*}{ Nilai } & \multirow{2}{*}{ Kategori } \\
\hline & & 1 & 2 & 3 & 4 & 5 & & & \\
\hline 1 & Memberikan apersepsi dan motivasi ketika membuka pelajaran & - & - & - & 4 & - & 4 & 80 & Baik \\
\hline 2 & Mengelola kelas & - & - & 3 & - & - & 3 & 60 & Baik \\
\hline 3 & Mengarahkan siswa & - & - & - & 4 & - & 4 & 80 & Baik \\
\hline 4 & $\begin{array}{l}\text { Menjelaskan topik, tujuan dan hasil belajar yang diharapkan dapat } \\
\text { dicapai oleh siswa. }\end{array}$ & - & - & 3 & & - & 3 & 60 & Baik \\
\hline 5 & $\begin{array}{l}\text { Menjelaskan pokok-pokok kegiatan yang harus dilakukan oleh siswa } \\
\text { untuk mencapai tujuan. }\end{array}$ & - & - & - & 4 & - & 4 & 80 & Baik \\
\hline 6 & Menjelaskan pentingnya topik dan kegiatan belajar & - & - & - & 4 & - & 4 & 80 & Baik \\
\hline 7 & Mengajukan pertanyaan yang relevan dengan materi yang disajikan & - & - & 3 & & - & 3 & 60 & Baik \\
\hline 8 & $\begin{array}{l}\text { Memberi pujian kepada siswa yang berusaha aktif dalam kegiatan tanya } \\
\text { jawab }\end{array}$ & - & - & - & 4 & - & 4 & 80 & Baik \\
\hline 9 & $\begin{array}{l}\text { Meluruskan atau mengarahkan jawaban yang disampaikan siswa, serta } \\
\text { mengajak siswa lain untuk saling melengkapi jawaban }\end{array}$ & - & - & - & 4 & - & 4 & 80 & Baik \\
\hline 10 & Mengajak siswa untuk menyimpulkan hasil tanya jawab & - & - & 3 & - & - & 3 & 60 & Baik \\
\hline 11 & Menyimpulkan hasil pembelajaran & - & - & - & 4 & - & 4 & 80 & Baik \\
\hline 12 & Evaluasi & - & - & 3 & - & - & 3 & 60 & Baik \\
\hline 13 & Memberikan penilaian terhadap hasil tes siswa & - & - & - & 4 & - & 4 & 80 & Baik \\
\hline 14 & Menutup pelajaran & - & - & - & 4 & - & 4 & 80 & Baik \\
\hline \multicolumn{2}{|c|}{\begin{tabular}{|l|} 
Jumlah skor \\
\end{tabular}} & 0 & 0 & 15 & 36 & 0 & 51 & 1020 & \\
\hline \multicolumn{2}{|c|}{ Rata-rata Persentase } & $0 \%$ & $0 \%$ & $36 \%$ & $64 \%$ & $0 \%$ & $100 \%$ & 72.9 & Baik \\
\hline
\end{tabular}

Sumber: Data hasil olahan penelitian, 2015

Data dari aktivitas guru terlihat pada lembaran observasi diatas, guru atau peneliti telah melaksanakan pembelajaran dengan baik. Peneliti mengajar dengan perngkat pembelajaran 
lengkap yakni da silabus, RPP, menguasai materi pelajaran, melakukan pengelolaan kels dengna baik.

\section{Siklus Kedua}

Data yang menunjukkan kegiatan siswa pada tindakan siklus I tercantum pada lembaran observasi. Pada lembaran observasi tergambar bahwa:

(1) Semangat atau motivasi belajar siswa saat penelitian ini dilakukan cukup baik. Penelitian yang diberikan pada lembaran observasi (A). Peneliti menyatakan hal ini karena pada saat kegiatan pembelajaran berlangsung semua siswa serius mendengarkan temannya bercerita di depan kelas. Di samping itu, siswa juga asik menyimak pidato yang dibagikan peneliti.

(2) Cara siswa mengerjakan tugas yang diberikan guru serius, dan proses pembelajaran berlangsung baik (nilai B dalam lembaran observasi). Semua siswa menyimak pidato dengan serius. Hal tersebut tidak terlepas dari pningkatan aktivitas guru dalm pembelajaran siklus II.

(3) TABEL 8

LEMBARAN AKTIVITAS SISWA SIKLUS II

\begin{tabular}{|c|c|c|c|c|c|c|c|c|c|c|c|c|c|c|c|c|c|c|}
\hline \multirow[b]{2}{*}{ No } & \multirow[b]{2}{*}{ Kode Sampel } & \multicolumn{14}{|c|}{ Aktivitas Siswa } & \multirow[b]{2}{*}{ Skor } & \multirow[b]{2}{*}{ Nilai } & \multirow[b]{2}{*}{ Kategori } \\
\hline & & 1 & 2 & & & & 6 & 7 & 8 & 9 & 10 & 11 & 12 & 13 & 14 & & & \\
\hline 1 & Adinda Fahira & 1 & 1 & 1 & 1 & 1 & 1 & 1 & 1 & 1 & 1 & 0 & 1 & 1 & 0 & 12 & 86 & Baik Sekali \\
\hline 2 & Aisyah Evlina & 1 & 1 & 0 & 1 & 1 & 0 & 1 & 1 & 1 & 1 & 1 & 1 & 1 & 1 & 12 & 86 & Baik Sekali \\
\hline 3 & Aldo Putra & 1 & 1 & 1 & 1 & 1 & 1 & 1 & 1 & 1 & 1 & 1 & 1 & 1 & 1 & 14 & 100 & Baik Sekali \\
\hline 4 & Ana Putra & 1 & 1 & 0 & 1 & 1 & 1 & 1 & 1 & 1 & 1 & 1 & 1 & 1 & 1 & 13 & 93 & Baik Sekali \\
\hline 5 & Andre Fajir Ananda & 1 & 1 & 1 & 1 & 1 & 1 & 1 & 1 & 1 & 1 & 1 & 1 & 1 & 1 & 14 & 100 & Baik Sekali \\
\hline 6 & andreas Ajis Saputra & 1 & 1 & 1 & 1 & 0 & 1 & 1 & 0 & 1 & 1 & 1 & 1 & 1 & 1 & 12 & 86 & Baik Sekali \\
\hline 7 & Anggi Riyanta & 1 & 1 & 1 & 1 & 1 & 0 & 1 & 1 & 1 & 1 & 1 & 1 & 1 & 1 & 13 & 93 & Baik Sekali \\
\hline 8 & Atsa Putri Jannah & 1 & 1 & 1 & 1 & 1 & 1 & 1 & 1 & 1 & 1 & 1 & 1 & 1 & 1 & 14 & 100 & Baik Sekali \\
\hline 9 & Astri Permata Sari & 1 & 0 & 1 & 1 & 1 & 1 & 1 & 1 & 1 & 1 & 0 & 1 & 0 & 1 & 11 & 79 & Baik \\
\hline 10 & Catur Ramadhan & 1 & 1 & 1 & 1 & 1 & 1 & 1 & 1 & 1 & 1 & 0 & 1 & 1 & 0 & 12 & 86 & Baik Sekali \\
\hline 11 & Devid Falen & 1 & 1 & 0 & 1 & 1 & 0 & 1 & 1 & 1 & 1 & 1 & 1 & 1 & 1 & 12 & 86 & Baik Sekali \\
\hline 12 & Dhea Sulastri Dasnan & 1 & 1 & 1 & 1 & 1 & 1 & 1 & 1 & 1 & 1 & 1 & 1 & 1 & 1 & 14 & 100 & Baik Sekali \\
\hline 13 & Elya Cintana Fahrezy & 1 & 1 & 0 & 1 & 1 & 1 & 1 & 1 & 1 & 1 & 1 & 1 & 1 & 1 & 13 & 93 & Baik Sekali \\
\hline 14 & Gempi Yuluandi & 1 & 1 & 1 & 1 & 1 & 1 & 1 & 1 & 1 & 1 & 1 & 1 & 1 & 1 & 14 & 100 & Baik Sekali \\
\hline 15 & Ismi Dehanindah & 1 & 1 & 1 & 1 & 0 & 1 & 1 & 0 & 1 & 1 & 1 & 1 & 1 & 1 & 12 & 86 & Baik Sekali \\
\hline 16 & Laray Baffi & 1 & 1 & 1 & 1 & 1 & 0 & 1 & 1 & 1 & 1 & 1 & 1 & 1 & 1 & 13 & 93 & Baik Sekali \\
\hline 17 & Mitra Lestari & 1 & 1 & 1 & 1 & 1 & 1 & 1 & 1 & 1 & 1 & 1 & 1 & 1 & 1 & 14 & 100 & Baik Sekali \\
\hline 18 & M. Akbar Zidang & 1 & 0 & 1 & 1 & 1 & 1 & 1 & 1 & 1 & 1 & 0 & 1 & 0 & 1 & 11 & 79 & Baik \\
\hline 19 & M. Farhan Athaullah & 1 & 1 & 1 & 1 & 1 & 1 & 1 & 1 & 1 & 1 & 0 & 1 & 1 & 0 & 12 & 86 & Baik Sekali \\
\hline 20 & M. Ikhsan Alfathan & 1 & 1 & 0 & 1 & 1 & 0 & 1 & 1 & 1 & 1 & 1 & 1 & 1 & 1 & 12 & 86 & Baik Sekali \\
\hline 21 & M. Salman & 1 & 1 & 1 & 1 & 1 & 1 & 1 & 1 & 1 & 1 & 1 & 1 & 1 & 1 & 14 & 100 & Baik Sekali \\
\hline 22 & M. Subarja & 1 & 1 & 0 & 1 & 1 & 1 & 1 & 1 & 1 & 1 & 1 & 1 & 1 & 1 & 13 & 93 & Baik Sekali \\
\hline 23 & Nabila Ariesta & 1 & 1 & 1 & 1 & 1 & 1 & 1 & 1 & 1 & 1 & 1 & 1 & 1 & 1 & 14 & 100 & Baik Sekali \\
\hline 24 & Nanda Nugroho & 1 & 1 & 1 & 1 & 0 & 1 & 1 & 0 & 1 & 1 & 1 & 1 & 1 & 1 & 12 & 86 & Baik Sekali \\
\hline 25 & Mathania Azaria & 1 & 1 & 1 & 1 & 0 & 1 & 1 & 1 & 1 & 1 & 1 & 1 & 1 & 1 & 13 & 93 & Baik Sekali \\
\hline 26 & Nurul Anjalina & 1 & 1 & 1 & 0 & 1 & 1 & 1 & 1 & 1 & 1 & 1 & 1 & 1 & 1 & 13 & 93 & Baik Sekali \\
\hline 27 & Nurul Annisa S & 0 & 1 & 1 & 1 & 0 & 1 & 1 & 1 & 1 & 1 & 1 & 1 & 1 & 1 & 12 & 86 & Baik Sekali \\
\hline 28 & Nyimas Adelia. H & 1 & 1 & 1 & 1 & 1 & 1 & 1 & 1 & 1 & 1 & 1 & 1 & 1 & 1 & 14 & 100 & Baik Sekali \\
\hline 29 & Puji Lestari & 1 & 1 & 0 & 1 & 1 & 1 & 1 & 1 & 0 & 1 & 1 & 1 & 1 & 1 & 12 & 86 & Baik Sekali \\
\hline 30 & Rahmad Dail & 1 & 1 & 1 & 0 & 1 & 1 & 0 & 1 & 1 & 1 & 1 & 1 & 0 & 1 & 11 & 79 & Baik \\
\hline 31 & Ridho Fadillah & 1 & 1 & 1 & 1 & 1 & 1 & 1 & 0 & 1 & 1 & 1 & 1 & 1 & 0 & 12 & 86 & Baik Sekali \\
\hline 32 & Rio Ahmad & 1 & 1 & 1 & 1 & 1 & 1 & 1 & 1 & 0 & 1 & 1 & 1 & 1 & 1 & 13 & 93 & Baik Sekali \\
\hline 33 & Riska Amelia Putri & 1 & 1 & 1 & 0 & 1 & 1 & 1 & 1 & 0 & 1 & 1 & 1 & 1 & 1 & 12 & 86 & Baik Sekali \\
\hline 34 & Siti Zharifah & 1 & 0 & 1 & 1 & 1 & 1 & 1 & 1 & 1 & 1 & 1 & 1 & 1 & 1 & 13 & 93 & Baik Sekali \\
\hline 35 & \begin{tabular}{|l|} 
Tahnia Ihsan Nuraini \\
\end{tabular} & 1 & 1 & 1 & 1 & 1 & 1 & 0 & 1 & 1 & 1 & 1 & 1 & 0 & 1 & 12 & 86 & Baik Sekali \\
\hline 36 & Taufik Hatta & 1 & 1 & 1 & 1 & 1 & 1 & 1 & 1 & 1 & 0 & 1 & 0 & 1 & 1 & 12 & 86 & Baik Sekali \\
\hline 37 & Trisna Amalia & 1 & 1 & 0 & 1 & 1 & 1 & 1 & 1 & 1 & 0 & 1 & 1 & 1 & 1 & 12 & 86 & Baik Sekali \\
\hline 38 & William Faranuari & 1 & 1 & 1 & 1 & 1 & 1 & 1 & 0 & 1 & 1 & 1 & 1 & 1 & 1 & 13 & 93 & Baik Sekali \\
\hline 39 & Yolanda & 1 & 1 & 1 & 1 & 1 & 1 & 1 & 1 & 1 & 1 & 1 & 1 & 1 & 1 & 14 & 100 & Baik Sekali \\
\hline 40 & Yudhi Pratama & 1 & 0 & 1 & 0 & 1 & 1 & 0 & 1 & 1 & 1 & 1 & 1 & 1 & 1 & 11 & 79 & Baik \\
\hline & Jumlah & 39 & 36 & 32 & 36 & 35 & 35 & 37 & 35 & 37 & 38 & 35 & 39 & 36 & 36 & 506 & 3614.3 & \\
\hline & Rata-rata & $98 \%$ & $90 \%$ & $80 \%$ & $90 \%$ & $88 \%$ & $88 \%$ & $93 \%$ & $88 \%$ & $93 \%$ & $95 \%$ & $88 \%$ & $98 \%$ & $90 \%$ & $90 \%$ & $1265 \%$ & $90.4 \%$ & Baik Sekali \\
\hline & Kategori & & & & & & & & & & & & & Baik & & & & \\
\hline
\end{tabular}

Sumber: Data hasil olahan penelitian, 2015

Sebagaimana terlihat pada lembaran observasi di atas, bahwa terlihat bahwa telah banyak siswa yang aktif, siswa mulai terfokus pada proses pembelajaran dengan meteri menyimak pidato. 
Berikut penulis paparkan tentang aktivitas guru selama melaksanakan tindakan siklus II.

TABEL 9

LEMBAR OBSERVASI GURU SIKLUS II

\begin{tabular}{|c|c|c|c|c|c|c|c|c|c|}
\hline \multirow[b]{2}{*}{ No } & \multirow[b]{2}{*}{ Aktivitas } & \multicolumn{5}{|c|}{ Skala nilai } & \multirow{2}{*}{ Skor } & \multirow{2}{*}{ Nilai } & \multirow{2}{*}{ Kategori } \\
\hline & & 1 & 2 & 3 & 4 & 5 & & & \\
\hline 1 & Memberikan apersepsi dan motivasi ketika membuka pelajaran & - & - & - & & 5 & 5 & 100 & Baik Sekali \\
\hline 2 & Mengelola kelas & - & - & - & - & 5 & 5 & 100 & Baik Sekali \\
\hline 3 & Mengarahkan siswa & - & - & - & - & 5 & 5 & 100 & Baik Sekali \\
\hline 4 & $\begin{array}{l}\text { Menjelaskan topik, tujuan dan hasil belajar yang diharapkan dapat } \\
\text { dicapai oleh siswa. }\end{array}$ & - & - & - & - & 5 & 5 & 100 & Baik Sekali \\
\hline 5 & $\begin{array}{l}\text { Menjelaskan pokok-pokok kegiatan yang harus dilakukan oleh siswa } \\
\text { untuk mencapai tujuan. }\end{array}$ & - & - & - & - & 5 & 5 & 100 & Baik Sekali \\
\hline 6 & Menjelaskan pentingnya topik dan kegiatan belajar & - & - & - & - & 5 & 5 & 100 & Baik Sekali \\
\hline 7 & Mengajukan pertanyaan yang relevan dengan materi yang disajikan & - & - & - & 4 & - & 4 & 80 & Baik \\
\hline 8 & $\begin{array}{l}\text { Memberi pujian kepada siswa yang berusaha aktif dalam kegiatan tanya } \\
\text { jawab }\end{array}$ & - & - & - & 4 & & 4 & 80 & Baik \\
\hline 9 & $\begin{array}{l}\text { Meluruskan atau mengarahkan jawaban yang disampaikan siswa, serta } \\
\text { mengajak siswa lain untuk saling melengkapi jawaban }\end{array}$ & - & - & - & - & 5 & 5 & 100 & Baik Sekali \\
\hline 10 & Mengajak siswa untuk menyimpulkan hasil tanya jawab & - & - & - & 4 & 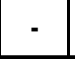 & 4 & 80 & Baik \\
\hline 11 & Menyimpulkan hasil pembelajaran & - & - & - & 4 & & 4 & 80 & Baik \\
\hline 12 & Evaluasi & - & - & - & & 5 & 5 & 100 & Baik Sekali \\
\hline 13 & Memberikan penilaian terhadap hasil tes siswa & - & - & - & & 5 & 5 & 100 & Baik Sekali \\
\hline 14 & Menutup pelajaran & - & - & - & - & 5 & 5 & 100 & Baik Sekali \\
\hline Juml & lah skor & 0 & 0 & 0 & 16 & 50 & 66 & 1320 & \\
\hline & -rata Persentase & $0 \%$ & $0 \%$ & $0 \%$ & $29 \%$ & $71 \%$ & $100 \%$ & 94.3 & Baik Sekali \\
\hline
\end{tabular}

Sumber: Data hasil olahan penelitian, 2015

Berdasarkan tabel observasi guru untuk siklus II, bahwa nilai rata-rata aktivitas guru menjadi 94.3 dengan kategori baik sekali. Dengan peningkatan aktivitas guru membawa pengaruh yang positif terhadap aktivitas siwa dalam proses pebelajaran. 
Hasil akhir dari pelaksanaan tindakan siklus II dapat dilihat pada tabel halaman berikut.

TABEL 10

DATA KEMAMPUAN MENYIMAK PIDATO SISWA KELAS IX. 2 SMP NEGERI 21 KOTA PEKANBARU SIKLUS II

\begin{tabular}{|c|c|c|c|c|c|c|}
\hline \multirow{3}{*}{ No } & \multirow{3}{*}{ Kode Sampel } & \multicolumn{3}{|c|}{ Indikator } & \multirow{3}{*}{ Jumlah Nilai } & \multirow{3}{*}{ Kategori } \\
\hline & & $\begin{array}{c}\text { TEMA } \\
\text { DIALOG }\end{array}$ & $\begin{array}{l}\text { PESAN } \\
\text { DIALOG }\end{array}$ & $\begin{array}{c}\text { KESIMPULA } \\
\text { N DIALOG }\end{array}$ & & \\
\hline & & 1 & 2 & 3 & & \\
\hline 1 & Adinda Fahira & 25 & 25 & 36 & 86 & Baik Sekali \\
\hline 2 & Aisyah Evlina & 22 & 23 & 36 & 81 & Baik Sekali \\
\hline 3 & Aldo Putra & 25 & 25 & 36 & 86 & Baik Sekali \\
\hline 4 & Ana Putra & 25 & 25 & 36 & 86 & Baik Sekali \\
\hline 5 & Andre Fajri Ananda & 23 & 25 & 36 & 84 & Baik Sekali \\
\hline 6 & andreas Ajis Saputra & 22 & 25 & 36 & 83 & Baik Sekali \\
\hline 7 & Anggi Riyanta & 25 & 25 & 36 & 86 & Baik Sekali \\
\hline 8 & Atsa Putri Jannah & 23 & 22 & 36 & 81 & Baik Sekali \\
\hline 9 & Astri Permata Sari & 25 & 25 & 35 & 85 & Baik Sekali \\
\hline 10 & Catur Ramadhan & 21 & 25 & 34 & 80 & Baik \\
\hline \begin{tabular}{|l|}
11 \\
\end{tabular} & Devid Falen & 24 & 25 & 35 & 84 & Baik Sekali \\
\hline 12 & Dhea Sulastri Dasnan & 25 & 23 & 35 & 83 & Baik Sekali \\
\hline 13 & Elya Cintana Fahrezy & 24 & 23 & 33 & 80 & Baik \\
\hline \begin{tabular}{|l|l|}
14 \\
\end{tabular} & Gempi Yuluandi & 22 & 23 & 36 & 81 & Baik Sekali \\
\hline 15 & Ismi Dehanindah & 22 & 23 & 35 & 80 & Baik \\
\hline \begin{tabular}{|l|}
16 \\
\end{tabular} & Laray Baffi & 25 & 25 & 36 & 86 & Baik Sekali \\
\hline \begin{tabular}{|l|l|}
17 \\
\end{tabular} & Mitra Lestari & 22 & 23 & 36 & 81 & Baik Sekali \\
\hline 18 & M. Akbar Zidang & 25 & 25 & 36 & 86 & Baik Sekali \\
\hline \begin{tabular}{|l|l|}
19 \\
\end{tabular} & M. Farhan Athaullah & 25 & 25 & 36 & 86 & Baik Sekali \\
\hline 20 & M. Ikhsan Alfathan & 23 & 25 & 36 & 84 & Baik Sekali \\
\hline 21 & M. Salman & 22 & 25 & 36 & 83 & Baik Sekali \\
\hline 22 & M. Subarja & 25 & 25 & 36 & 86 & Baik Sekali \\
\hline \begin{tabular}{|l|}
23 \\
\end{tabular} & Nabila Ariesta & 23 & 22 & 36 & 81 & Baik Sekali \\
\hline \begin{tabular}{|l|l|}
24 \\
\end{tabular} & Nanda Nugroho & 25 & 25 & 35 & 85 & Baik Sekali \\
\hline \begin{tabular}{|l|}
25 \\
\end{tabular} & Mathania Azaria & 21 & 25 & 34 & 80 & Baik \\
\hline 26 & Nurul Anjalina & 24 & 25 & 35 & 84 & Baik Sekali \\
\hline 27 & Nurul Annisa S & 25 & 23 & 35 & 83 & Baik Sekali \\
\hline \begin{tabular}{|l|l|}
28 \\
\end{tabular} & Nyimas Adelia. $\mathrm{H}$ & 24 & 23 & 33 & 80 & Baik \\
\hline \begin{tabular}{|l|}
29 \\
\end{tabular} & Puji Lestari & 22 & 23 & 36 & 81 & Baik Sekali \\
\hline 30 & Rahmad Dail & 22 & 23 & 35 & 80 & Baik \\
\hline \begin{tabular}{|l|}
31 \\
\end{tabular} & Ridho Fadillah & 25 & 25 & 31 & 81 & Baik Sekali \\
\hline \begin{tabular}{|l|}
32 \\
\end{tabular} & Rio Ahmad & 25 & 24 & 35 & 84 & Baik Sekali \\
\hline 33 & Riska Amelia Putri & 22 & 23 & 36 & 81 & Baik Sekali \\
\hline \begin{tabular}{|l|l|}
34 \\
\end{tabular} & Siti Zharifah & 22 & 25 & 36 & 83 & Baik Sekali \\
\hline 35 & Tahnia Ihsan Nuraini & 25 & 23 & 33 & 81 & Baik Sekali \\
\hline 36 & Taufik Hatta & 21 & 25 & 34 & 80 & Baik \\
\hline 37 & Trisna Amalia & 23 & 22 & 36 & 81 & Baik Sekali \\
\hline 38 & William Faranuari & 25 & 26 & 35 & 86 & Baik Sekali \\
\hline 39 & Yolanda & 21 & 25 & 34 & 80 & Baik \\
\hline 40 & Yudhi Pratama & 22 & 25 & 36 & 83 & Baik Sekali \\
\hline & Jumlah & 937 & 967 & 1408 & 3312 & \\
\hline & Rata-rata & 23.4 & 24.2 & 35.2 & 82.8 & Baik Sekali \\
\hline
\end{tabular}

Sumber: Data hasil olahan penelitian, 2015

Berdasarkan tabel diatas, bahwa kemampuan siswa dala menyimak pidato yang dinilai dalam 3 aspek penilaian, diperoleh nilai rata-rata siswa 82.8 dengan kategori baik sekali. 


\section{Pembahasan}

Rekapitulasi perbandingan data awal, siklus I dan Siklus II terhadap kemampuan menyimak pidato siswa kelas IX. 2 dapat dilihat pada tabel berikut.

TABEL 12

PERBANDINGAN HASIL BELAJAR AWAL, SIKLUS I, DAN SIKLUS II

\begin{tabular}{|c|c|c|c|c|c|}
\hline \multirow[b]{2}{*}{ No } & \multirow[b]{2}{*}{ Kode } & \multicolumn{4}{|c|}{ Nilai Akhir } \\
\hline & & Data Awal & Siklus I & Siklus II & Keterangan \\
\hline 1 & Adinda Fahira & 58 & 80 & 86 & Meningkat \\
\hline 2 & Aisyah Evlina & 79 & 81 & 81 & Meningkat \\
\hline 3 & Aldo Putra & 53 & 60 & 86 & Meningkat \\
\hline 4 & Ana Putra & 58 & 65 & 86 & Meningkat \\
\hline 5 & Andre Fajri Ananda & 61 & 64 & 84 & Meningkat \\
\hline 6 & andreas Ajis Saputra & 62 & 65 & 83 & Meningkat \\
\hline 7 & Anggi Riyanta & 58 & 64 & 86 & Meningkat \\
\hline 8 & Atsa Putri Jannah & 56 & 81 & 81 & Meningkat \\
\hline 9 & Astri Permata Sari & 80 & 81 & 85 & Meningkat \\
\hline 10 & Catur Ramadhan & 57 & 80 & 80 & Meningkat \\
\hline 11 & Devid Falen & 79 & 84 & 84 & Meningkat \\
\hline 12 & Dhea Sulastri Dasnan & 57 & 80 & 83 & Meningkat \\
\hline 13 & Elya Cintana Fahrezy & 58 & 81 & 80 & Meningkat \\
\hline 14 & Gempi Yuluandi & 60 & 60 & 81 & Meningkat \\
\hline 15 & Ismi Dehanindah & 60 & 65 & 80 & Meningkat \\
\hline 16 & Laray Baffi & 58 & 64 & 86 & Meningkat \\
\hline 17 & Mitra Lestari & 79 & 65 & 81 & Meningkat \\
\hline 18 & M. Akbar Zidang & 53 & 64 & 86 & Meningkat \\
\hline 19 & M. Farhan Athaullah & 58 & 81 & 86 & Meningkat \\
\hline 20 & M. Ikhsan Alfathan & 61 & 81 & 84 & Meningkat \\
\hline 21 & M. Salman & 62 & 80 & 83 & Meningkat \\
\hline 22 & M. Subarja & 58 & 84 & 86 & Meningkat \\
\hline 23 & Nabila Ariesta & 56 & 80 & 81 & Meningkat \\
\hline 24 & Nanda Nugroho & 80 & 81 & 85 & Meningkat \\
\hline 25 & Mathania Azaria & 57 & 60 & 80 & Meningkat \\
\hline 26 & Nurul Anjalina & 79 & 65 & 84 & Meningkat \\
\hline 27 & Nurul Annisa S & 57 & 63 & 83 & Meningkat \\
\hline 28 & Nyimas Adelia. $\mathrm{H}$ & 58 & 62 & 80 & Meningkat \\
\hline 29 & Puji Lestari & 60 & 61 & 81 & Meningkat \\
\hline 30 & Rahmad Dail & 60 & 65 & 80 & Meningkat \\
\hline 31 & Ridho Fadillah & 54 & 60 & 81 & Meningkat \\
\hline 32 & Rio Ahmad & 60 & 60 & 84 & Meningkat \\
\hline 33 & Riska Amelia Putri & 60 & 70 & 81 & Meningkat \\
\hline 34 & Siti Zharifah & 58 & 79 & 83 & Meningkat \\
\hline 35 & Tahnia Ihsan Nuraini & 79 & 81 & 81 & Meningkat \\
\hline 36 & Taufik Hatta & 58 & 84 & 80 & Meningkat \\
\hline 37 & Trisna Amalia & 58 & 84 & 81 & Meningkat \\
\hline 38 & William Faranuari & 54 & 63 & 86 & Meningkat \\
\hline 39 & Yolanda & 60 & 70 & 80 & Meningkat \\
\hline 40 & Yudhi Pratama & 67 & 67 & 83 & Meningkat \\
\hline & Jumlah & 2480 & 2865 & 3312 & Meningkat \\
\hline & Rata-rata & 62.0 & 71.6 & 82.8 & Meningkat \\
\hline & Kategori & & & kat & \\
\hline
\end{tabular}

Sumber: Data hasil olahan penelitian, 2015

Berdasarkan data dari tabel 14 terlihat adanya peningkatan kemampuan menyimak pidato dengan metode tanya jawab siswa kelas IX . 2 SMP Negeri 21 Kota Pekanbaru dari data awal, Siklus I dan II. Peningkatan terjadi pada seluruh siswa kelas yang menjadi objek .Perubahan ini terjadi dari tes awal, siklus I, dan siklus II. Data peningkatan nilai siswa ini dapat dilihat pada histogram berikut ini.

\section{GRAFIK 1}

GRAFIK PENINGKATAN KEMAMPUAN MENYIMAK PIDATO

(DATA AWAL, SIKLUS I DAN II)

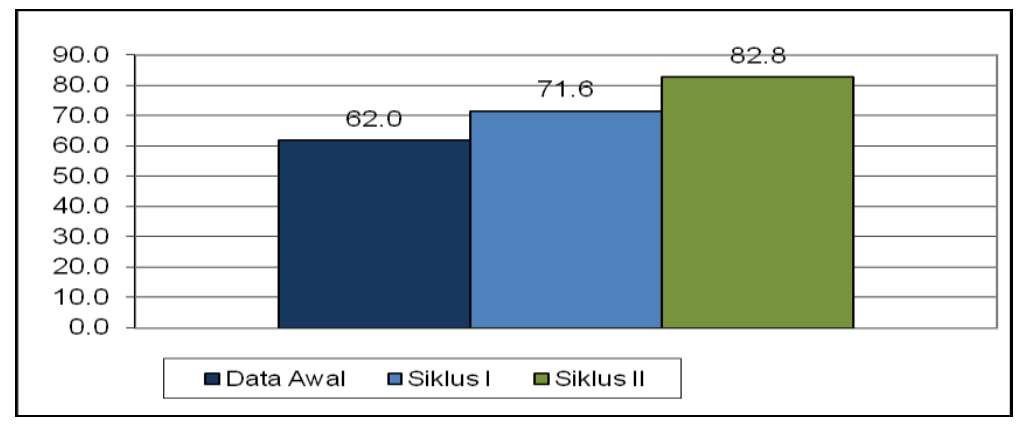




\section{Analisis Data}

Pada penelitian ini diperoleh hasil analisis data dari analisis daya serap dan ketuntasan hasil belajar siswa. Adapun aspek-aspek yang dianalisis :

\section{Daya Serap atau kemampuan siswa}

Daya serap merupakan indeks atau tingkat pemahaman dari tiap siswa terhadap materi yang diberikan. Berdasarkan data yang diperoleh tentang daya serap siswa pada materi pokok kemampuan menyimak pidato dengan metode kooperatif terhadap siswa dapat dilihat pada tabel berikut.

TABEL 13

REKAPITULASI KEMAMPUAN MENYIMAK PIDATO PADA TES AWAL, SIKLUS I DAN SIKLUS II

\begin{tabular}{|c|c|c|c|c|c|}
\hline \multirow{2}{*}{ No } & \multirow{2}{*}{ Interval (\%) } & Kategori & Tes Awal & Siklus I & Siklus II \\
\cline { 4 - 6 } & $81-100$ & Baik Sekali & $0 \%$ & $30 \%$ & $80 \%$ \\
\hline 2 & $60-80$ & Baik & $48 \%$ & $70 \%$ & $20 \%$ \\
\hline 3 & $41-59$ & Cukup & $53 \%$ & $0 \%$ & $0 \%$ \\
\hline 4 & $21-40$ & Kurang & $0 \%$ & $0 \%$ & $0 \%$ \\
\hline 5 & $0-20$ & Sangat kurang & $0 \%$ & $0 \%$ & $0 \%$ \\
\hline$\%$ & $100 \%$ & $100 \%$ & $100 \%$ \\
\hline \multicolumn{7}{|c|}{ Jumlah Siswa } & 62.0 & 71.6 & 82.8 \\
\hline
\end{tabular}

Sumber: Data Hasil Olahan Penelitian, Tahun 2015

Dari tabel 15 tersebut, dapat dijelaskan bahwa kemampuan rata-rata siswa pada tes awal dikategorikan baik dengan nilai rata-rata 62.0 pada siklus I kemampuan rata-rata siswa dikategorikan baik dengan nilai 71.6, sedangkan pada siklus II kemampuan rata-rata siswa dikategorikan baik dengan persentase $82.8 \%$. dan rata-rata keseluruhannya 72.1 dengan kategori baik.

\section{Ketuntasan Hasil Belajar Siswa} tabel berikut.

Ketuntasan belajar siswa pada materi kemampuan menyimak pidato dapat dilihat dari

TABEL 14. KETUNTASAN HASIL BELAJAR SISWA TES AWAL, SIKLUS I DAN SIKLUS II

\begin{tabular}{|c|c|c|c|c|}
\hline \multicolumn{2}{|c|}{ Ketuntasan Belajar Siswa } & Nilai & $\%$ & Kategori \\
\hline \multirow{2}{*}{ Tes Awal } & Tuntas & 7 & $18 \%$ & \multirow{2}{*}{ TT } \\
\cline { 2 - 4 } & Tidak Tuntas & 33 & $83 \%$ & \\
\hline \multirow{2}{*}{ Siklus I } & Tuntas & 18 & $45 \%$ & \multirow{2}{*}{ T } \\
\cline { 2 - 4 } & Tidak Tuntas & 22 & $55 \%$ & \\
\hline \multirow{2}{*}{ Siklus II } & Tuntas & 40 & $100 \%$ & \multirow{2}{*}{$\mathrm{T}$} \\
\cline { 2 - 4 } & Tidak Tuntas & 0 & $0 \%$ & \\
\hline
\end{tabular}

Sumber: Data hasil olahan penelitian, 2015

Berdasarkan dari tabel di atas, dapat dinyatakan bahwa secara klasikal persentase ketuntasan pada materi pokok kemampuan menyimak pidato dengan metode tanya jawab pada siswa kelas IX. 2 SMP Negeri 21 Kota Pekanbaru adalah 40 siswa dinyatakan tuntas dengan persentase $100 \%$. Ketuntasan hasil belajar pada tes awal, Siklus I dan Siklus II juga ditampilkan dalam bentuk histogram pada halaman berikut. 
GRAFIK 2

GRAFIK KETUNTASAN HASIL BELAJAR SISWA

PADA TES AWAL, SIKLUS I DAN SIKLUS II

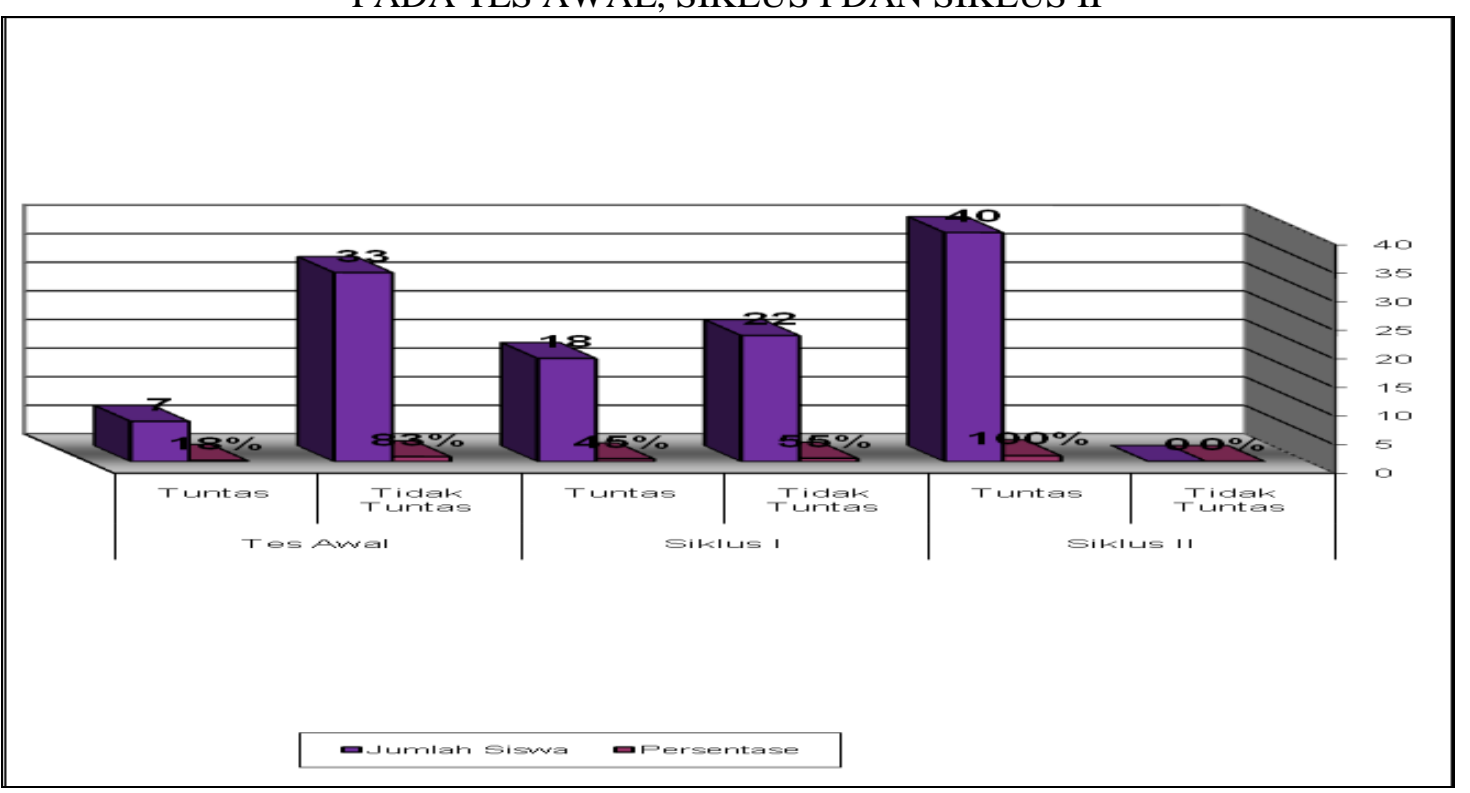

\section{Keterangan:}

1. Tes Awal

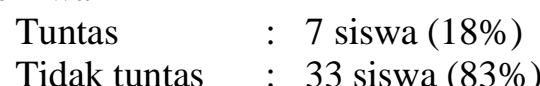

2. Siklus I

Tuntas $\quad: 18$ siswa $(45 \%)$

3. Siklus II

Tidak tuntas : 22 siswa $(55 \%)$

$\begin{array}{ll}\text { Tuntas } & : 40 \text { siswa }(100 \%) \\ \text { Tidak tuntas } & : 0 \text { siswa }(0,0 \%)\end{array}$

\section{Aktivitas Siswa}

Aktivitas siswa dalam proses belajar mengajar dapat diamati dengan menggunakan lembar observasi pada setiap pertemuan. Hasil rata-rata aktivitas siswa pada siklus I dan siklus II tersebut dapat dilihat pada tabel 18 berikut. 
TABEL 15

RATA-RATA PERSENTASE AKTIVITAS SISWA SIKLUS I DAN SIKLUS II

\begin{tabular}{|c|c|c|c|c|c|c|}
\hline \multirow{2}{*}{ No } & \multirow{2}{*}{ Aktivitas yang Diamati } & \multicolumn{2}{|c|}{ Siklus I } & \multicolumn{2}{|c|}{ Siklus II } & \multirow{2}{*}{ Rata-Rata } \\
\hline & & $\mathrm{N}$ & $\%$ & $\mathrm{~N}$ & $\%$ & \\
\hline 1 & $\begin{array}{l}\text { Memperhatikan penjelasan guru dengan penuh } \\
\text { khidmat }\end{array}$ & 22 & $55.0 \%$ & 39 & $97.5 \%$ & $76.3 \%$ \\
\hline 2 & $\begin{array}{l}\text { Memperhatikan dan melaksanakan perintah } \\
\text { guru }\end{array}$ & 20 & $50.0 \%$ & 36 & $90.0 \%$ & $70.0 \%$ \\
\hline 3 & Memperhatiakan pengarahan guru & 25 & $62.5 \%$ & 32 & $80.0 \%$ & $71.3 \%$ \\
\hline 4 & $\begin{array}{l}\text { Mendengarkan penjelasan guru tentang topik, } \\
\text { tujuan dan hasil belajar yang diharapkan dapat } \\
\text { dicapai }\end{array}$ & 26 & $65.0 \%$ & 36 & $90.0 \%$ & $77.5 \%$ \\
\hline 5 & $\begin{array}{l}\text { Mendengarkan pokok-pokok kegiatan yang } \\
\text { harus dilakukan untuk mencapai tujuan }\end{array}$ & 23 & $57.5 \%$ & 35 & $87.5 \%$ & $72.5 \%$ \\
\hline 6 & $\begin{array}{l}\text { Mendengarkan pentingnya topik dan kegiatan } \\
\text { belajar }\end{array}$ & 23 & $57.5 \%$ & 35 & $87.5 \%$ & $72.5 \%$ \\
\hline 7 & Menjawab pertanyaan guru & 26 & $65.0 \%$ & 37 & $92.5 \%$ & $78.8 \%$ \\
\hline 8 & Aktif dalam kegiatan tanya jawab & 28 & $70.0 \%$ & 35 & $87.5 \%$ & $78.8 \%$ \\
\hline 9 & Menyimpulkan hasil tanya jawab & 26 & $65.0 \%$ & 37 & $92.5 \%$ & $78.8 \%$ \\
\hline 10 & Menjawab pertanyaan guru dengan benar & 26 & $65.0 \%$ & 38 & $95.0 \%$ & $80.0 \%$ \\
\hline 11 & Mengikuti evaluasi dengan baik & 27 & $67.5 \%$ & 35 & $87.5 \%$ & $77.5 \%$ \\
\hline 12 & Menerima hasil penilaian dari guru & 29 & $72.5 \%$ & 39 & $97.5 \%$ & $85.0 \%$ \\
\hline 13 & $\begin{array}{l}\text { Mendengarkan penyampaian guru diakhir } \\
\text { pembelajaran }\end{array}$ & 31 & $77.5 \%$ & 36 & $90.0 \%$ & $83.8 \%$ \\
\hline 14 & Mengikuti guru menutup pelajaran & 28 & $70.0 \%$ & 36 & $90.0 \%$ & $80.0 \%$ \\
\hline \multicolumn{2}{|c|}{ Jumlah skor } & 360 & $900 \%$ & 506 & $1265 \%$ & 21.65 \\
\hline \multicolumn{2}{|c|}{ Rata-rata } & & $64.3 \%$ & & $90.4 \%$ & $77.3 \%$ \\
\hline
\end{tabular}

Sumber: Data hasil olahan penelitian, 2015

Berdasarkan dari tabel di atas, dapat disimpulkan bahwa masing-masing aktivitas siswa selama pembelajaran berlangsung bervariasi, ada siswa yang kurang serius mengikuti pelajaran dengan baik dan ada juga yang kurang serius dalam mengikuti pelajaran. Perolehan nilai aktivitas siswa dalam 14 aspek yang dijadikan penilaian antara lain dari aspek siswa memperhatikan penjelasan guru dengan penuh khidmat, memperoleh nilai rata-rata dengan persentase $77.3 \%$. Memperhatikan dan melaksanakan perintah guru, memperoleh nilai rata-rata dengan persentase 64.3\% . Memperhatiakan pengarahan, memperoleh nilai rata-rata dengan persentase $90.4 \%$. Mendengarkan penjelasan guru tentang topik, tujuan dan hasil belajar yang diharapkan dapat dicapaiuru, memperoleh nilai rata-rata dengan persentase $74,0 \%$. Mendengarkan pokok-pokok kegiatan yang harus dilakukan untuk mencapai tujuan, memperoleh nilai rata-rata dengan persentase $72,0 \%$. Mendengarkan pentingnya topik dan kegiatan belajar, memperoleh nilai ratarata dengan persentase $74,0 \%$. Menjawab pertanyaan guru, memperoleh nilai rata-rata dengan persentase $78,0 \%$. Aktif dalam kegiatan tanya jawab, memperoleh nilai rata-rata dengan persentase $80,0 \%$. Menyimpulkan hasil tanya jawab, memperoleh nilai rata-rata dengan persentase $76,0 \%$. Menjawab pertanyaan guru dengan benar, memperoleh nilai rata-rata dengan persentase $78,0 \%$. Mengikuti evaluasi dengan baik, memperoleh nilai rata-rata dengan persentase $80,0 \%$. Menerima hasil penilaian dari guru, memperoleh nilai rata-rata dengan persentase $84 \%$. Mendengarkan penyampaian guru diakhir pembelajaran, memperoleh nilai rata-rata dengan persentase $82 \%$. Mengikuti guru menutup pelajaran, memperoleh nilai rata-rata dengan persentase $82 \%$.

Dari hasil penjabaran sebelumnya, diketahui bahwa secara garis besar terjadi peningkatan aktivitas siswa dari siklus I ke Siklus II. Keadaan ini seiring dengan peningkatan aktivitas guru yang ditingkatkan, sehingga memberikan pengaruh yang positif terhadap aktivitas siswa selama pembelajaran.

\section{Aktivitas Guru}

Aktivitas guru selama pembelajaran pada siklus I dan siklus II dengan materi kemampuan menyimak pidato dapat dianalisa seperti tabel berikut ini. 
TABEL 16. AKTIVITAS GURU SIKLUS I DAN SIKLUS II

\begin{tabular}{|c|c|c|c|}
\hline No & Siklus & Aktivitas $\%$ & Kategori \\
\hline 1 & Siklus I & 72.9 & Baik \\
\hline 2 & Siklus II & 94.3 & Baik Sekali \\
\hline \multicolumn{2}{|c|}{ Rata-rata } & 83.6 & Baik Sekali \\
\hline
\end{tabular}

Berdasarkan tabel 16 bahwa aktivitas guru selama pengajaran tentang materi menyimak pidato. Pada siklus I aktivitas guru tercapai $72.9 \%$ dengan kategori baik. Pada siklus II aktivitas guru meningkat dengan persentase 94,3\% dengan kategori baik, dan rata-rata keseluruhannya 83,6 dengan kategori baik.

\section{KESIMPULAN}

Berdasarkan hasil penelitian, maka diperoleh kesimpulan terhadap penelitian ini adalah untuk meningkatkan kemampuan menyimak pidato dengan metode tanya jawab pada siswa kelas IX.2 SMP Negeri 21 Kota Pekanbaru.

Rata-rata siswa pada tes awal dikategorikan baik dengan nilai rata-rata 62 dan pada siklus I naik menjadi 71,6 dengan kategori baik, sedangkan pada siklus II kemampuan rata-rata siswa juga dikategorikan baik dengan nilai rata-rata 82.8 , tetapi dengan ketuntasan $100 \%$, dimana nilai ketuntasan siswa telah tercapi.

Pernyataan di atas menunjukkan bahwa kemampuan menyimak pidato denga metode tanya jawab pada siswa kelas IX.2 SMP Negeri 21 Kota Pekanbaru dapat ditingkatkan melalui metode tanya jawab. Dengan demikian hipotesis penelitian yang berbunyi Peningkatan Menyimak Pidato Denga Metode Tanya Jawab Pada Siswa Kelas IX SMP Negeri 21 Kota Pekanbaru dapat "diterima".

\section{SARAN}

Kurangnya pemahaman siswa dalam memahami aspek-aspek yang terkandung dalam suatu pidato, baik sifat bahan, pengorganisasian bahan dan bahasa bahan sebaiknya dilakukan perbaikan dengan melakukan tanya jawab pada setiap sesi pelajaran dan mengulas pembelajaran dengan menanyakan kepada siswa materi yang telah dipelajari.Untuk meningkatkan kemampuan menyimak pidato di sekolah diharapkan kepada Guru Bahasa Indonesia dan Sastra dapat menggunakan metode tanya jawab.

\section{DAFTAR PUSTAKA}

[1] Dimyati dan Mudjiono, 2002. Belajar dan Pembelajaran. Jakarta: Rineka Cipta

[2] Djamarah. 2000. Guru dan Anak didik Dalam Interaksi Edukatif. Jakarta: Rineka Cipta.

[3] Kunandar. 2007. Guru Profesional Implementasi Kurikulum Tingkat Satuan Pendidikan (KTSP) Dan Persiapan Menghadapi Sertifikasi Guru. Jakarta: PT. Raja Grafindo Persada.

[4] Mulyasa, E, 2007. Menjadi Guru Profesional Menciptakan Pembelajaran Kreatif dan Menyenangkan. Bandung: Rosda.

[5] Mukhtar dan Anilawati, 2006. Menyimak. Pekanbaru: Cendikia Insani

[6] Nurhadi, dkk. 2007. Bahasa Indonesia untuk SMP Kelas IX. Jakarta: Erlangga

[7] Razak, 2003. Bahasa Indonesia Versi Perguruan Tinggi. Pekanbaru: Autografika.

[8] Roestiyah, 2001. Strategi Belajar Mengajar. Jakarta: Rineka Cipta.

[9] Safari. 2005. Penulisan Butir Soal Berdasarkan Penilaian Berbasis Kompetensi. Jakarta: Apsi Pusat.

[10] Sanjaya, Wina. 2007. Strategi Pembelajaran Berorientasi Standar Proses Pendidikan. :Jakarta. Kencana, 